\title{
Perkawinan Lintas Agama Perspektif Hukum Positif dan Hukum Agama di Indonesia
}

\author{
Dwiyana Achmad Hartanto \\ Universitas Muria Kudus \\ dwiyana.achmad@umk.ac.id
}

\begin{abstract}
Abstrak
Praktek perkawinan antar agama di Indonesia menurut hukum positif dan hukum agama merupakan suatu permasalahan yang krusial. Pada dasarnya secara hukum dengan melihat ketentuan pada Undang-Undang Nomor 1 Tahun 1974 Tentang Perkawinan dan Instruksi Presiden Nomor 1 tahun 1991 Tentang Kompilasi Hukum Islam, sebenarnya pengaturan mengenai pelarangan perkawinan lintas agama sudah jelas. Secara hukum agama yang ada di Indonesia secara tegas juga melarang perkawinan beda agama, atau membolehkan dengan syarat-syarat yang sangat berat dilakukan. Akan tetapi atas dasar rasa cinta, HAM, dan alasan lainnya perkawinan lintas agama masih banyak tejadi yang dapat disiasati melalui beberapa cara. Namun pada kenyataannya perkawinan lintas agama dapat menimbulkan berbagai permasalahan yang dihadapi oleh suami isteri yang berbeda agama, terkait dengan kehidupan rumah tangga yang dijalani, serta tujuan perkawinan yang hendak dicapai. Selain itu dari segi keabsahan suatu perkawinan UndangUndang Nomor 1 Tahun 1974 Tentang Perkawinan mengembalikan keabsahan perkawinan kepada ranah atau kewenangan agama dan kepercayaan masingmasing agamanya, sehingga sah tidaknya perkawinan bergantung pada ketentuan hukum agama.
\end{abstract}

Kata Kunci: Perkawinan, Lintas Agama, Hukum Positif, Agama.

\begin{abstract}
The practice of interfaith marriage in Indonesia according to positive law and religious law is a crucial problem. Basically legally by looking at the provisions in Law Number 1 of 1974 concerning Marriage and Presidential Instruction Number 1 of 1991 concerning Compilation of Islamic Law, the actual regulation regarding the prohibition of interfaith marriages is clear. By law, religious religions in Indonesia explicitly also prohibit interfaith marriages, or allow with very severe conditions to be carried out. But on the basis of love, human rights, and other reasons interfaith marriages still occur that can be circumvented in a number of ways. But in reality interfaith marriages can cause various problems faced by husband and wife of different religions, related to the domestic life lived, and the purpose of marriage to be achieved. In addition, in terms of the validity of a marriage Law No. 1 of 1974 concerning Marriage returns the validity of marriage to the realm or authority of the religion and beliefs of each religion, so that the validity of marriage depends on the provisions of religious law.
\end{abstract}

Keywords: Marriage, Interfaith, Positive Law, Religion. 


\section{A. Pendahuluan}

Perkawinan merupakan salah satu lembaga yang diciptakan Allah SWT sebagai sarana untuk meneruskan keturunan atau generasi di samping sebagai sarana untuk memenuhi kebutuhan biologis, menghindari perzinaan, serta membentuk sebuah keluarga yang merupakan pranata yang paling kecil dalam lingkup kehidupan masyarakat. Banyak definisi yang diberikan oleh para ahli, baik dalam lingkup Hukum Perdata, Hukum Adat, maupun Hukum Islam. Pengertian Perkawinan menurut ketentuan Pasal 1 Undang-Undang Nomor 1 Tahun 1974 Tentang Perkawinan (selanjutnya disebut Undang-Undang Perkawinan) adalah ikatan lahir bathin antara seorang pria dengan seorang wanita sebagai suami isteri dengan tujuan membentuk keluarga (rumah tangga) yang bahagia dan kekal berdasarkan Ketuhanan Yang Maha Esa.

Mendasarkan pada pengertian di atas, tujuan dilangsungkannya sebuah perkawinan adalah sebagai bentuk ikatan lahir batin suami isteri yang kekal dengan mendasarkan pada aspek Ketuhanan Yang Maha Esa. Artinya suatu perkawinan mengandung aspek agama yang berkaitan erat dengan ajaran agama yang dianutnya. Setiap agama mempunyai syarat dan rukun tersendiri dalam mengatur pelaksanaan suatu perkawinan, sehingga keabsahan suatu perkawinan ditentukan oleh hukum agama dan kepercayaannya masing-masing. Hal ini sebagaiman ketentuan dalam Pasal 2 ayat (1) Undang-Undang Perkawinan, bahwa Perkawinan adalah sah, apabila di lakukan menurut hukum masing-masing agamanya dan kepercayaannya itu.

Keabsahan suatu perkawinan bergantung pada syarat dan rukun yang diatur di dalam ketentuan agama. Secara umum syaratsyarat perkawinan dalam berbagai agama hampir sama yang pada intinya adalah menyatukan seorang pria dengan seorang wanita menjadi sepasang suami isteri, akan tetapi persyaratan terhadap agama atau keyakinan calon mempelai menjadi hal yang perlu mendapat perhatian. Agama mensyaratkan bahwa antara calon suami dengan calon isteri hendaknya mempunyai agama yang sama, karena sahnya perkawinan merupakan kewenangan agama, di mana untuk sahnya suatu perkawinan harus dilakukan menurut agama tertentu. Selain itu apakah mungkin tujuan keluarga yang bahagia dan kekal berdasarkan Ketuhanan Yang Maha Esa dapat tercapai apabila masing-masing berbeda agama dan bagaimana pendidikan agama yang diberikan kepada anak-anak mereka, serta bagaimana hak dan kewajiban yang timbul dari suatu perkawinan lintas agama yang dilakukan misalnya terkait dengan perwalian dan pewarisan. 
Ketentuan mengenai syarat dan rukun perkawinan ini terkadang diabaikan oleh sebagian orang dengan mendasarkan pada ketentuan hak asasi manusia dan atas dasar rasa cinta di antara mereka. Sehingga kita dapat menjumpai beberapa orang yang melakukan praktek perkawinan lintas agama, dengan cara mengajukan permohonan terlebih dahulu kepada Pengadilan Negeri, karena lembaga agama menolak untuk mengawinkan mereka sebagai suami isteri dengan alasan perbedaan agama. Mendasarkan pada uraian di atas, menarik untuk dilakukan kajian bagaimana pandangan terhadap perkawinan lintas agama di Indonesia baik menurut hukum positif maupun hukum agama?

\section{B. Landasan Teori}

\section{Pengertian Perkawinan}

Banyak pengertian perkawinan yang diberikan oleh para ahli hukum maupun perundang-undangan. Pengertian perkawinan menurut ketentuan Pasal 1 Undang-Undang Perkawinan, bahwa perkawinan ialah ikatan lahir bathin antara seorang pria dengan seorang wanita sebagai suami isteri dengan tujuan membentuk keluarga (rumah tangga) yang bahagia dan kekal berdasarkn ketuhanan Yang Maha Esa. Sedangkan menurut ketentuan Pasal 2 Kompilasi Hukum Islam yang ditetapkan dengan Instruksi Presiden Nomor 1 Tahun 1991 (selanjutnya disebut Kompilasi Hukum Islam), Perkawinan adalah pernikahan, yaitu akad yang sangat kuat atau miitsaaqan ghaliidhan untuk menaati perintah Allah dan melaksanakannya merupakan ibadah.

Menurut bahasa, perkawinan berasal dari kata kawin yang identik dengan nikah yang berasal dari bahasa Arab, yang berarti menghimpun, berkumpul, dan menindas. Sedangkan menurut istilah berarti akad yang menghalalkan pergaulan antara laki-laki dan perempuan yang bukan mahrom yang menimbulkan hak dan kewajiban antara keduanya. (Syarafudin HZ, et al, 2003: 94). Sedangkan menurut M. Idris Ramulyo, perkawinan adalah perjanjian suci membentuk keluarga antara seorang laki-laki dengan seorang perempuan. Perjanjian di sini adalah adanya ijab, yaitu penawaran yang sah dari pihak wali perempuan atau wakilnya dan adanya qabul, yaitu penerimaan yang sah dari pihak calon pengantin laki-laki atau wakilnya.(Moh. Idris Ramulyo, 2002: 16). Perkawinan menurut hukum Islam adalah suatu akad atau perikatan untuk menghalalkan hubungan kelamin antara laki-laki dan perempuan dalam rangka mewujudkan kebahagiaan hidup keluarga, yang diliputi rasa ketenteraman serta kasih saying 
dengan cara yang diridhai Allah (KH. Ahmad Azhar Basyir, 2004, 14).

Menurut hukum adat, perkawinan adalah implementasi perintah Tuhan yang melembaga dalam masyarakat untuk membentuk rumah tangga dalam ikatan-ikatan kekeluargaan.(Otje Salman Soemadiningrat, 2002, 173). Sementara itu Iman Sudiyat menyatakan bahwa perkawinan para warganya (pria, wanita atau kedua-duanya) adalah sarana untuk melangsungkan hidup kelompoknya secara tertib teratur, sarana yang dapat melahirkan generasi baru yang melanjutkan garis hidup kelompoknya. (Iman Sudiyat, 1981, 107). Perkawinan merupakan salah satu budaya yang beraturan yang mengikuti perkembangan budaya manusia dalam kehidupan masyarakat. Budaya perkawinan dan aturannya yang berlaku pada suatu masyarakat atau pada suatu bangsa tidak terlepas dari pengaruh budaya dan lingkungan di mana masyarakat itu berada serta pergaulan masyarakatnya yang dipengaruhi oleh pengetahuan, pengalaman, kepercayaan, dan keagamaan yang dianut masyarakat bersangkutan.(Hilman Hadikusuma, 2007: 1).

Perkawinan menurut Kitab Undang-Undang Hukum Perdata (KUH Perdata) merupakan pertalian yang sah antara seorang lelaki dan seorang perempuan untuk waktu yang lama. Undang-undang memandang perkawinan sebagai hubungan keperdataan, sebagaimana ketentuan pasal 26 KUH Perdata. Sehingga perkawinan yang sah adalah perkawinan yang memenuhi syarat-syarat yang ditetapkan dalam KUH Perdata, dan syarat-syarat dan peraturan agama dikesampingkan. (Subekti, 1989: 23).

Melihat berbagai pengertian di atas mengenai perkawinan terdapat berbagai macam pengertian, namun pada dasarnya dalam memberikan pengertian tentang perkawinan adalah sama-sama menyebutkan adanya ikatan atau akad antara seorang laki-laki dengan seorang perempuan untuk membentuk sebuah keluarga.

\section{Sahnya Perkawinan}

Mengenai sah atau tidaknya suatu perkawinan, perkawinan harus dilaksanakan sesuai dengan hukum masing-masing agama dan kepercayaannya yang memenuhi rukun dan persyaratan sesuai dengan agama masing-masing. Hal ini sebagaimana dituangkan dalam ketentuan pasal 2 ayat (1) UUP : Perkawinan adalah sah apabila dilakukan menurut hukum masing-masing agama dan kepercayaannya itu. KHI menegaskan ketentuan pasal tersebut bahwa Perkawinan adalah sah, apabila dilakukan menurut hukum 
Islam sesuai dengan pasal 2 ayat (1) UUP. Menurut hukum Islam, perkawinan adalah sah apabila telah memenuhi rukun nikah yaitu calon suami, calon istri, wali nikah, dua orang saksi, ijab dan qobul.

Menurut ketentuan Undang-Undang Perkawinan mengenai syarat-syarat perkawinan dapat dibedakan menjadi syarat formil dan syarat materiil. Ketentuan mengenai syarat-syarat tersebut antara lain dapat dilihat di dalam ketentuan Pasal 6 UndangUndang Perkawinan:

(1) Perkawinan harus didasarkan atas persetujuan kedua calon mempelai.

(2) Untuk melangsungkan perkawinan seorang yang belum mencapai umur 21 (dua puluh satu) tahun harus mendapat izin kedua orang tua.

(3) Dalam hal salah seorang dari kedua orang tua telah meninggal dunia atau dalam keadaan tidak mampu menyatakan kehendaknya, maka izin dimaksud ayat (2) pasal ini cukup diperoleh dari orang tua yang masih hidup atau dari orang tua yang mampu menyatakan kehendaknya.

(4) Dalam hal kedua orang tua telah meninggal dunia atau dalam keadaan tidak mampu untuk menyatakan kehendaknya maka izin diperoleh dari wali, orang yang memelihara atau keluarga yang mempunyai hubungan darah dalam garis keturunan, lurus ke atas selama mereka masih hidup dan dalam keadaan dapat menyatakan kehendaknya.

(5) Dalam hal ada perbedaan pendapat antara orang-orang yang dalam ayat (2), (3) dan (4), pasal ini atau salah seorang atau diantara mereka tidak menyatakan pendapatnya, maka Pengadilan dalam daerah hukum tempat tinggal orang yang melangsungkan perkawinan atas permintaan orang tersebut memberikan izin setelah lebih dahulu mendengar orang-orang tersebut dalam ayat (2), (3) dan (4) pasal ini.

(6) Ketentuan tersebut ayat (1) sampai dengan ayat (5) pasal berlaku sepanjang hukum masing-masing agamanya dan kepercayaannya itu dari yang bersangkutan tidak menentukan lain.

Mengenai pelarangan perkawinan juga disebutkan dalam ketentuan Pasal 8 Undang-Undang Perkawinan, bahwa:

Perkawinan dilarang antara dua orang yang :

a. berhubungan darah dalam garis keturunan lurus ke bawah ataupun ke atas;

b. berhubungan darah, dalam garis keturunan menyamping yaitu antar saudara, antara seorang dengan saudara orang tua dan antara seorang dengan saudara neneknya; 
c. sehubungan semenda, yaitu mertua, anak tiri, menantu dan bapak tiri;

d. sehubungan susunan, yaitu orang tua susuan, anak susuan, saudara susuan dan bibi/paman susuan;

e. sehubungan saudara dengan isteri atau sebagai bibi atau kemenekan dari isteri, dalam hal seorang suami beristeri lebih dari seorang;

f. mempunyai hubungan yang oleh agamanya atau peraturan yang berlaku, dilarang kawin.

Mengenai syarat dan rukun perkawinan menurut Kompilasi Hukum Islam dapat dilihat di dalam ketentuan Pasal 14 Kompilasi Hukum Islam:

Untuk melaksanakan perkawinan harus ada :

a. Calon Suami;

b. Calon Isteri;

c. Wali nikah;

d. Dua orang saksi dan;

e. Ijab dan Kabul.

Selanjutnya disebutkan di dalam ketentuan Pasal 15 dan 16 Kompilasi Hukum Islam. Pasal 15:

(1) Untuk kemaslahatan keluarga dan rumah tangga, perkawinan hanya boleh dilakukan calon mempelai yang telah mencapai umur yang ditetapkan dalam pasal 7 Undang-Undang No.1 Tahun 1974 yakni calon suami sekurang-kurangnya berumur 19 tahun dan calon isteri sekurangkurangnya berumur 16 tahun.

(2) Bagi calon mempelai yang belum mencapai umur 21 tahun harus mendapati izin sebagaimana yang diatur dalam pasal 6 ayat (2), (3), (4) dan (5) UU No.1 Tahun 1974.

Pasal 16:

(1) Perkawinan didasarkan atas persetujuan calon mempelai.

(2) Bentuk persetujuan calon mempelai wanita, dapat berupa pernyataan tegas dan nyata dengan tulisan, lisan atau isyarat tapi dapat juga berupa diam dalam arti selama tidak ada penolakan yang tegas.

Selain syarat dan rukun di atas, Kompilasi Hukum Islam juga mengatur mengenai dilarangnya suatu perkawinan di mana salah satu calon mempelai beragama non Islam, yaitu ditentukan di dalam ketentuan Pasal 40 dan Pasal 44 Kompilasi Hukum Islam. Pasal 40:

Dilarang melangsungkan perkawinan antara seorang pria dengan seorang wanita karena keadaan tertentu:

a. karena wanita yang bersangkutan masih terikat satu perkawinan dengan pria lain; 
b. seorang wanita yang masih berada dalam masa iddah dengan pria lain;

c. seorang wanita yang tidak beragama Islam.

Ketentuan lain terkait larangan menikah lintas agama juga diatur di dalam ketentuan Pasal 44 Kompilasi Hukum Islam, Seorang wanita Islam dilarang melangsungkan perkawinan dengan seorang pria yang tidak beragama Islam.

Berdasarkan ketentuan-ketentuan mengenai syarat dan rukun perkawinan yang ada di dalam ketentuan Undang-Undang Perkawinan dan Kompilasi Hukum Islam, maka jelas bahwa perkawinan yang hendak dilakukan hendaknya memenuhi ketentuan-ketentuan syarat dan rukun di atas, sehingga apabila syarat dan rukun di atas tidak terpenuhi akan berakibat pada tidak sahnya suatu perkawinan.

\section{Perkawinan Lintas Agama}

Secara umum menurut Abdul Hafidz sebagaimana dikutip Siska Lis Sulistiani, perkawinan lintas agama adalah perkawinan antara dua orang yang memeluk (menganut) agama yang berbeda dan salah satunya beragama Islam, sementara yang satunya memeluk agama selain Islam (non muslim). (Siska Lis Sulistiani, 2015: 45). Perkawinan beda agama merupakan suatu perkawinan yang dilakukan oleh orang-orang yang memeluk agama dan kepercayaan yang berbeda antara yang satu dengan yang lain, misalnya perkawinan antara seorang pria muslim dengan seorang wanita protestan atau sebaliknya.(Abdurrachman dan Ridwan Syahrani, 1978: 20). Sebelum dikeluarkannya Undang-Undang Perkawinan, negara kita telah memiliki 3 (tiga) bentuk pengaturan tentang perkawinan campuran. Ketiga peraturan tersebut adalah :

1. Kitab Undang-Undang Hukum Perdata (Burgerlijke Wetboek);

2. Ordonansi Perkawinan Indonesia Kristen (Huwelijks Ordinantie Christen Indonesia (HOCI) S. 1933 No. 74);

3. Peraturan Perkawinan Campuran (Regeling op de gemengde Huwelijken S. 1898 No. 158).

Ketiga produk peraturan itulah yang digunakan dalam pengaturan perkawinan yang berlangsung di Indonesia. Setelah berlakunya Undang-Undang Nomor 1 Tahun 1974 tentang Perkawinan, maka ketiga produk peraturan tersebut dinyatakan tidak berlaku sepanjang ketentuannya sudah diatur dalam UndangUndang Perkawinan. Ketentuan ini diatur dalam Pasal 66 UndangUndang Perkawinan: “Untuk perkawinan dan segala sesuatu yang berhubungan dengan perkawinan berdasarkan atas Undangundang ini, maka dengan berlakunya Undang-undang ini 
ketentuan-ketentuan yang diatur dalam Kitab Undang-undang Hukum Perdata (Burgerlijk Wetboek), Ordonansi Perkawinan Indonesia Kristen (Howelijks, Ordonnantie Christen Indonesiers S. 1933 No.74 ), Peraturan Perkawinan Campuran (Regeling op de gemengde Huwelijken S. 1898 No. 158), dan peraturan-peraturan lain yang mengatur tentang perkawinan sejauh telah diatur dalam Undang-undang ini, dinyatakan tidak berlaku".

Undang-Undang Perkawinan tidak mengatur terkait perkawinan beda agama, tetapi mengatur tentang perkawinan campuran antar 2 (dua) orang warga negara Indonesia dan warga negara asing. Pengertian perkawinan campuran dapat dilihat dalam ketentuan Pasal 55 Undang-Undang Perkawinan, yaitu: "Perkawinan yang dimaksud dengan perkawinan campuran dalam Undang-undang ini ialah perkawinan antara dua orang yang di Indonesia tunduk pada hukum yang berlainan, karena perbedaan kewarganegaraan salah satu pihak berkewarganegaraan Indonesia".

Perkawinan beda agama tidak diatur dalam UndangUndang Perkawinan, karena pada dasarnya undang-undang ini bernafaskan keagamaan, sebagaimana dalam ketentuan Pasal 1 Undang-Undang Perkawinan, bahwa perkawinan ialah ikatan lahir bathin antara seorang pria dengan seorang wanita sebagai suami isteri dengan tujuan membentuk keluarga (rumah tangga) yang bahagia dan kekal berdasarkn ketuhanan Yang Maha Esa. Dengan demikian tujuan yang ingin dicapai dalam perkawinan berdasarkan Ketuhanan Yang Maha Esa, di mana tujuan tersebut dapat tercapai dengan baik apabila dalam satu keluarga mempunyai satu visi dan misi keagamaan yang sama.

Menurut ketentuan Undang-Undang Perkawinan, suatu perkawinan yang sah harus memenuhi rukun dan syarat perkawinan, sehingga perkawinan yang akan dilakukan harus memperhatikan larangan-larangan perkawinan (M. Idris Ramulyo, 1974: 34) :

a. Larangan perkawinan karena berlainan agama;

b. Larangan perkawinan karena hubungan darah yang terlampau dekat;

c. Larangan perkawinan karena hubungan susuan;

d. Larangan perkawinan karena hubungan semenda;

e. Larangan perkawinan polyandri.

f. Larangan perkawinan terhadap wanita yang dili'an;

g. Larangan perkawinan (menikahi) wanita/pria pezina;

h. Larangan perkawinan dari bekas suami terhadap isteri (bekas isteri yang ditalak tiga); 
i. Larangan perkawinan bagi pria yang telah beristeri empat.

Menurut Agama Islam, larangan perkawinan lintas agama mendasarkan pada ketentuan Surat Al-Baqarahn ayat 221: “Dan janganlah kamu nikahi wanita-wanita musyrik sebelum mereka beriman, sesungguhnya wanita budak yang mukmin lebih baik dari pada wanita musyrik walaupun dia menarik hatimu. Dan janganlah kamu menikahkan orang-orang musyrik dengan wanitawanita mukmin sebelum mereka beriman, sesungguhnya budak yang mukmin lebih baik dari orang musyrik, walaupun dia menarik hatimu. Mereka mengajak ke neraka, sedangkan Allah mengajak ke surga dan ampunan dengan izinnya. Dan Allah menerangkan perintah-perintahNya kepada manusia, supaya mereka mengambil pelajaran".

\section{Pembahasan}

\section{Perkawinan Lintas Agama Menurut Agama-Agama di Indonesia}

Perkawinan lintas agama menurut agama-agama yang ada di Indonesia dapat dibedakan menjadi sebagai berikut:

1. Menurut Agama Islam (Siman Dahwal, 2016: 88-103)

a. Perkawinan antara seorang pria muslim dengan wanita musyrik. Perkawinan jenis ini menurut kesepakatan mayoritas ulama adalah mutlak terlarang yang mendasarkan pada ketentuan surat Al-Baqarah: 221.

b. Perkawinan antara seorang pria muslim dengan ahlul kitab.

Pada perkawinan jenis ini Allah SWT memberikan dispensasi hak atau kewenangan pria muslim mengawini wanita ahlul kitab, yang mendasarkan pada ketentuan surat Al-Maidah: 5. Dalam hal ini terdapat 3 (tiga) pendapat: 1) hak atau kewenangan tersebut boleh digunakan pria muslim jika ia mau menggunakannya; 2) dispensasi yang diberikan boleh dilakukan dengan syarat sebagaimana surat An-Nisa': 25, antara lain karena susahnya mendapatkan wanita muslim, syarat kemampuan dan iman harus terpenuhi (untuk menentukan arah pendidikan anak-anaknya dan isterinya secara Islam); dan 3) mengharamkan perkawinan tersebut karena kerusakannya lebih besar dari pada kebaikannya bagi kehidupan keluarga, terutama bagi kehidupan anak-anak yang lahir dari perkawinan berbeda agama itu. Hal ini juga diharamkan oleh fatwa MUI yang dikeluarkan tanggal 1 Juni 1980.

c. Perkawinan antara seorang wanita muslimah dengan pria musyrik. 
Perkawinan jenis ini menurut kesepakatan mayoritas ulama adalah mutlak terlarang yang mendasarkan pada ketentuan surat Al-Baqarah: 221 dan surat Al-Mumtahanah: 10.

2. Menurut Agama Nasrani

a. Agama Katolik (Siman Dahwal, 2016: 112-113)

Menurut agama Katolik perkawinan antara seorang yang beragama Katolik dengan seorang yang tidak beragama Katolik tidak merupakan pasangan yang serasi atau ideal, karena agama Katolik menghendaki perkawinan antara seorang pria dengan wanita seiman atau seagama. Bahkan agama Katolik dengan tegas menyatakan bahwa perkawinan antara seorang Katolik dengan penganut agama lain,tidak sah. Kalaupun ada dispensasi yang diberikan Gereja, maka dengan persyaratan-persyaratan: 1) menerima perkawinan secara Katolik; 2) tidak akan menceraikan pihak yang beragama Katolik; 3) tidak akan menghalangi pihak Katolik melaksanakan imannya; 4) bersedia mendidik anakanaknya secara Katolik. Sebaliknya pihak yang beragama Katolik juga berjanji: 1) setia pada iman Katolik; 2) berusaha mempermandikan dan mendidik anak-anak mereka secara Katolik. Walaupun dapat diberikan dispensasi nanum dalam pandangan agama Katolik perkawinan lintas agama akan menimbulkan berbagai konflik dan pertentangan dalam kehidupan keluarga yang dapat berupa konflik iman, konflik batin, konflik hak asasi terhadap anak, konflik kejiwaan dan kebingungan pada anak.

b. Agama Protestan (Siman Dahwal, 2016, 114)

Agama Kristen Protestan tidak melarang umatnya kawin dengan orang yang bukan beragama Kristen Protestan, akan tetapi pada prinsipnya menghendaki perkawinan yang seagama, karena tujuan utama perkawinan menurut agama Kristen Protestan adalah kebahagiaan, dan kebahagiaan akan sulit tercapai kalau tidak seiman atau seagama. Kalaupun Gereja memberikan ijin, maka ada persyaratan yang harus dipenuhi, yaitu: 1) bagi yang beragama Kristen Protestan harus menandatangani perjanjian: a) tetap melaksanakan iman Kristennya; b) akan membaptis anakanak yang dilahirkan dalam perkawinan secara Kristen; c) berjanji akan mendidik anak-anak mereka secara Kristen, sedangkan 2) bagi mereka yang beragama bukan Kristen Protestan harus menandatangani perjanjian: a) tidak keberatan perkawinan dilaksanakan di Gereja Protestan; b) tidak keberatan anak-anak mereka dididik secara Kristen Protestan.

3. Menurut Agama Hindu (Siman Dahwal, 2016: 122) 
Dalam agama Hindu ditentukan bahwa yang harus diperhatikan dalam melansungkan perkawinan adalah agama, karena menurut agama Hindu perkawinan hanya dapat disahkan apabila kedua mempelai telah menganut agama Hindu. Apabila kedua mempelai atau salah satunya belum beragama Hindu, maka perkawinan tidak dapat disahkan dan Brahmana (pendeta) baru mengesahkan perkawinan tersebut apabila pihak yang bukan Hindu telah disahkan sebagai pemeluk agama Hindu.

4. Menurut Agama Budha (Siman Dahwal, 2016: 125)

Pada prinsipnya agama Budha menghendaki calon suami isteri adalah sama-sama beragama Budha. Apabila salah satu beragama lain, maka kepada mereka diberikan surat keterangan yang disertai janji dari calon mempelai untuk tetap memegang ajaran Budha dan untuk keperluan melaksankan perkawinan di kantor catatan sipil, sehingga dapat melindungi kedua calon mempelai untuk menjalani hidup bersama dalam suatu ikatan perkawinan yang dibenarkan menurut ajaran Budha dan Undang-Undang.

5. Menurut Agama Khonghuchu (Siman Dahwal, 2016: 128)

Menurut agama Khonghuchu, tidak mempersoalkan keagamaan dalam perkawinan, baik untuk pria maupun wanita, walaupun berbeda keyakinan atau kepercayaan diserahkan kepada penganutnya masing-masing. Artinya agama Khonghuchu memberikan kebebasan kepada umatnya untuk menentukan pilihan pasangan mereka sesuai dengan keinginan masing-masing.

\section{Praktek Perkawinan Lintas Agama di Indonesia}

Sebelum diundangkannya Undang-Undang Perkawinan, praktek perkawinan yang berlaku di Indonesia bermacam-macam, sehingga di Indonesia berlaku berbagai hukum perkawinan yang berlaku bagi berbagai golongan Warga Negara Indonesia, yaitu : 1) Bagi orang-orang Indonesia asli yang beragama Islam berlaku hukum agama yang telah diresepsi oleh hukum adat (teori receptio in complexu yang kemudian dibantah teori receptie), misalnya praktek perkawinan yang dilaksanakan sesuai ajaran Islam. 2) bagi orang-orang Indonesia asli lainnya berlaku hukum adat, misalnya bagi orang Bali yang beragama Hindu (hukum adat dan agama telah menyatu) maka pelaksanaan perkawinan dilaksanakan sesuai hukum adat Hindu Bali yang dianutnya. 3) bagi orang Indonesia asli yang beragama Kristen berlaku Huwelijks Ordonantie Christen Indonesia (HOCI) S. 1933 Nomor 74. 4) bagi orang-orang Timur Asing Cina dan Warga Negara Indonesia keturunan Cina berlaku ketentuan-ketentuan dalam Kitab Undang-undang Hukum Perdata (KUH Perdata) dengan sedikit perubahan. 5) bagi orang-orang Timur Asing lainnya dan Warga 
Negara Indonesia keturunan asing lainnya tersebut berlaku hukum adat mereka. Misalnya keturunan India, Pakistan, Arab, dan lainnya berlaku hukum adat masing-masing mereka yang tidak terlepas dari agama dan kepercayaan yang dianutnya. 6) bagi orang-orang Eropa dan yang disamakan dengan mereka, berlaku Kitab Undang-undang Hukum Perdata (KUH Perdata), termasuk orang Jepang atau orangorang lain yang menganut asas-asas hukum keluarga yang sama dengan asas-asas hukum keluarga Belanda.

Adanya aneka ragam peraturan mengenai pelaksanaan perkawinan menjadikan praktek perkawinan yang muncul terkadang saling benrtentangan antara ajaran agama dan perundang-undangan, misalnya terkait perkawinan lintas agama yang menurut ajaran agama dilarang, akan tetapi menurut peraturan-peraturan yang ada diperbolehkan, sehingga keadaan yang demikian akan menyulitkan lembaga agama yang bertugas melakukan pencatatan perkawinan dan kantor catatan sipil yang mempunyai salah satu fungsi melakukan pencatatan perkawinan.

Adanya ketentuan di dalam Pasal 26 KUH Perdata dan Pasal 1 Ordonansi Perkawinan Indonesia-Kristen mengatur sebagai berikut, bahwa di dalam ketentuan Pasal 26 KUH Perdata menyatakan bahwa "Undang-undang memandang soal perkawinan hanya dalam hubungan-hubungan perdata". Sementara ketentuan Pasal 1 Ordonansi Perkawinan Indonesia-Kristen menyatakan bahwa perkawinan oleh Undang-Undang hanya dianggap sebagai hubungan sipil saja. Menurut kedua ketentuan di atas terdapat pemisahan antara civil marriage dengan religius marriage, sehingga suatu perkawinan yang tunduk pada hukum tersebut maka sah atau tidaknya suatu perkawinan tergantung pada syarat dan-syarat yang tertulis dalam Undang-Undang atau tidak, sedangkan syarat-syarat menurut agama dikesampingkan.(M. Idris Ramulya, 1990: 140).

Pada saat sebelum diundangkannya Undang-Undang Perkawinan, dengan adanya beragam peraturan mengenai perkawinan, perkawinan antar agama diatur oleh Peraturan Perkawinan Campuran (GHR). Selain itu, HOCI juga mengatur perkawinan beda agama, sehingga penyelenggaraan perkawinan beda agama tidak menjadi permasalahan dan dapat dicatat di dalam daftar perkawinan campuran kantor catatan sipil. Diundangkannya UndangUndang Perkawinan yang merupakan unifikasi hukum perkawinan di Indonesia, di mana dalam ketentuannya tidak mengatur mengenai perkawinan lintas agama karena sah dan tidaknya perkawinan merupakan kewenangan ranah agama.

Undang-Undang Perkawinan tidak mengatur mengenai perkawinan lintas agama, karena perkawinan tersebut tidak 
dibenarkan ajaran agama, yaitu ada halangan terjadinya perkawinan bagi calon suami dan calon isteri karena perbedaan agama. Hal ini sesuai dengan ketentuan Pasal 2 ayat 1 Undang-Undang perkawinan, bahwa "Perkawinan adalah sah, apabila di lakukan menurut hukum masing-masing agamanya dan kepercayaannya itu". Ketentuan Pasal ini jelas bahwa perkawinan sah apabila telah sesuai dengan hukum agama dan kepercayaannya itu. Sedangkan di dalam penjelasan Pasal ini, tidak ada perkawinan di luar hukum masing-masing agamanya dan kepercayaannya itu sesuai dengan Undang-Undang Dasar 1945.

Menurut Hazairin ditegaskan bahwa bagi orang Islam tidak ada kemungkinan untuk kawin dengan melanggar hukum agama sendiri, demikian juga bagi orang Kristen dan bagi orang Hindu atau Hindu Budha. Menurut Hukum Islam tidak sah perkawinan antar agama sebagaimana ketentuan Al-Qur'an Surat Al-Baqarah: 221. Dari pandangan agama Kristen secara tegas juga dapat dilihat dalam ketentuan Al-Kitab dalam Perjanjian Baru (Korintus 6: 14). Dengan adanya Undang-Undang Perkawinan Pasal 166 yang berbunyi: "Untuk perkawinan dan segala sesuatu yang berhubungan dengan perkawinan berdasarkan atas Undang-Undang ini, maka dengan berlakunya Undang-Undang ini ketentuan-ketentuan yang diatur dalam Kitab Undang-Undang Hukum Perdata (Burgerlijk Wetboek), Ordonansi Perkawinan Indonesia Kristen (Howelijks Ordonnantie Christen Indonesiers S. 1933 No.74 ), Peraturan Perkawinan Campuran (Regeling op de gemengde Huwelijken S. 1898 No. 158), dan peraturan-peraturan lain yang mengatur tentang perkawinan sejauh telah diatur dalam Undang-undang ini, dinyatakan tidak berlaku.

Menurut Maria Ulfah Subadio, penyelenggaraan perkawinan agama sebenarnya masih dapat dilakukan berdasarkan peraturan lama (GHR dan HOCI). Adanya Keppres No. 12/1983 tentang Penataan dan Peningkatan Pembinaan dan Penyelenggaraan Catatan Sipil, di dalam ketentuan Pasal 1 bahwa kantor catatan sipil diberi kewenanagan pencatatan dan penerbitan kutipan akta-akta bagi mereka yang bukan beragama Islam. Ketentuan inilah yang menjadikan kantor catatan sipil tidak mau melangsungkan perkawinan lintas agama karena berpendapat bahwa kantor catatan sipil tidak memiliki kewenangan tersebut. Namun ada juga beberapa kantor catatan sipil yang masih mau melangsungkan dan mencatat perkawinan litas agama dengan dasar Pasal 20 Undang-Undang Perkawinan, yang menentukan bahwa Pegawai Pencatat Perkawinan melangsungkan atau membantu melangsungkan perkawinan. Atau juga mendasarkan pada ketentuan Pasal 21 Undang-Undang Perkawinan, yaitu melalui prosedur Pengadilan Negeri terlebih 
dahulu dan sesuai dengan Surat Edaran Mahkamah Agung, kantor catatan sipil secara historis dianggap berwenang melangsungkan perkawinan lintas agama. Dalam praktek juga terjadi, perkawinan antar agama dilakukan perkawinan 2 (dua) kali, yaitu menurut agama suami dan kemudian menurut agama isteri.(Sunaryati Hartono, 1991: 147-148).

Perkawinan lintas agama yang berlangsung di Indonesia sebagaimana dikemukakan Wahyono Damabrata, bahwa ada 3 (tiga) cara yang lazim ditempuh bagi pasangan lintas agama yang mau menikah, yaitu sebagai berikut (Simon Dahwal, 2016: 137-138) :

1. Meminta penetapan pengadilan terlebih dahulu. Atas dasar penetapan itulah pasangan perkawinan melakukan perkawinan di kantor catatan sipil, akan tetapi sejak diterbitkan Keppres No. 12 Tahun 1983 hal ini sudah tidak dapat dilakukan lagi.

2. Perkawinan dilakukan menurut hukum masing-masing agama, yaitu perkawinan terlebih dahulu dilaksanakan menurut agama seorang mempelai (biasanya suami), baru disusul perkawinan menurut agama mempelai berikutnya. Yang menjadi permasalahan adalah perkawinan mana yang dianggap sah? Jika perkawinan menurut hukum yang kedua, maka menjadi persoalan mengenai status perkawinan pertama. Selain itu kedua pihak menentukan pilihan hukum, artinya salah satu pihak tunduk pada hukum pasangannya, sehingga salah seorang pasangan berpindah agama sebagai bentuk penundukan hukum.

3. Melangsungkan perkawinan di luar negeri. Cara yang ketiga inilah yang sering dilakukan oleh mereka yang melakukan praktek perkawinan lintas agama.

Dalam prakteknya perkawinan lintas agama dilakukan melalui 3 (tiga) cara tersebut di atas. Sebagai contoh praktek perkawinan lintas agama yang dilakukan melalui penetapan dari pengadilan antara lain sebagai berikut: 1) Yurisprudensi MA Register No. 1400/K/Pdt/1986 (perkawinan lintas agama antara Andi Vonny Gani P (wanita Islam) dengan Adrianus Petrus Hendrik Nelwan (laki-laki Kristen Protestan)); 2) Penetapan Pengadilan Negeri Jakarta Selatan No. 238/Pdt/P/1986/PN Jkt.Sel (Perkawinan lintas agama antara Jamal Mirdad dengan Lydia Kandou); 3) Penetapan Pengadilan Negeri No. 21/Pdt/P/2001/PN Kabupaten Semarang (Perkawinan lintas agama antara Roy Candra Lesmana dengan Rina Ayuningsih Nareswati); 4) Putusan Pengadilan Negeri Pati Nomor 85/Pdt.P/2014/PN Pti (Perkawinan lintas agama Bambang Yanuardi (agama Islam) dengan Listia Anggelina (agama Kristen)). 


\section{Pandangan Terhadap Perkawinan Lintas Agama Di Indonesia Baik Menurut Hukum Positif Maupun Hukum Agama.}

Perkawinan merupakan suatu perbuatan hukum yang suci dan sakral dalam pandangan agama atau kepercayaan apapun. Dalam Undang-Undang Pekawinan sebagai unifikasi hukum perkawinan nasional, perkawinan merupakan ikatan lahir batin antara seorang pria dengan seorang wanita sebagai suami isteri dengan tujuan membentuk keluarga (rumah tangga) yang bahagia dan kekal berdasarkan Ketuhanan Yang Maha Esa. Merujuk definisi tersebut, maka perkawinan mempunyai dua aspek hubungan, yaitu hubungan sesama makhluk antara pria dan wanita beserta keluarga keduanya, serta hubungan makhluk dengan Tuhannya karena perkawinan mempunyai tujuan tercapaianya suatu kebahagiaan berdasarkan Ketuhanan Yang Maha Esa.

Tujuan perkawinan yang mempunyai dimensi ibadah dan berhubungan erat dengan dimensi keagamaan. Tujuan tersebut dapat tecapai dengan baik apabila perkawinan dilakukan oleh pasangan yang mempunyai agama yang sama. Adanya tujuan keagamaan yang ingin dicapai tersebut, maka Undang-Undang Pekawinan tidak mengatur ketentuan mengenai adanya perkawinan lintas agama, melainkan hanya mengatur mengenai perkawinan campuran antara warga negara Indonesia dengan warga negara asing. Bagaimana mungkin suatu tujuan membina keluarga yang bahagia dan kekal berdasarkan Ketuhanan Yang Maha Esa dapat tercapai apabila seorang suami dan isteri mempunyai keyakinan yang berbeda. Bagaimana mereka akan menegakkan agama yang mereka yakini kalau keduanya berbeda keyakinan, di mana ritual ibadahnya berbeda, larangan dan anjuran dalam kehidupan agama juga berbeda. Ketika dalam perkawinan lintas agama tersebut sudah mempunyai keturunan, akan membawa persoalan kembali, akan dididik dan diajarkan kehidupan berdasarkan hukum agama apa anak tersebut. Tentu anak juga akan menjadi bingung melihat keyakinan orang tuanya yang berbeda. Terlebih apabila salah satu suami atau isteri yang beragama Islam, ketika salah satunya meninggal dunia maka akan menyebabkan putusnya hubungan waris di antara mereka, karena konsep waris dalam hukum Islam adalah antara Muslim dengan Non Muslim adalah tidak saling mewarisi.

Ketentuan Pasal 2 ayat (1) Undang-Undang Pekawinan menyatakan bahwa Perkawinan adalah sah, apabila dilakukan menurut hukum masing-masing agamanya dan kepercayaannya itu. Penafsiran terhadap ketentuan ini menyatakan bahwa keabsahan perkawinan dikembalikan kepada hukum masing-masing agama dan kepercayaan yang dianut pelaku perkawinan. Karena masing-masing 
agama mempunyai ketentuan tersendiri mengenai syarat-syarat dan rukun-rukun yang harus dipenuhi dalam perkawinan. Sebagai contoh dalam agama Islam, syarat agama kedua calon suami dan isteri adalah keduanya beragama Islam. Dalam ajaran agama Kristen juga demikian. Kalaupun itu dilakukan, lantas siapa yang akan menikahkan mereka? baik pihak Kantor Urusan Agama maupun pihak Gereja menolak untuk melangsungkan perkawinan.

Menurut Moh. Idris Ramulyo menyatakan bahwa dalam pelaksanaan Undang-Undang Perkawinan tidak mengatur perkawinan antar agama, karena perkawinan tersebut tidak dibenarkan ajaran, yaitu ada halangan terjadinya perkawinan bagi calon suami dan calon isteri yang berbeda agama, hal ini sesuai dengan ketentuan Pasal 2 ayat (1), bahwa Perkawinan adalah sah, apabila dilakukan menurut hukum masing-masing agamanya dan kepercayaannya itu. Menurutnya pasal tersebut terang dan jelas bahwa hukum agama dan kepercayaannya masing-masing berlaku bagi pemeluknya, sedangkan penjelasan Pasal 2 menyatakan tidak ada perkawinan di luar hukum masing-masing agama dan kepercayaannya itu. Bahkan menurut Hazairin ditegaskan lagi bahwa tidak ada kemungkinan untuk kawin dengan melanggar hukum agama sendiri.(Moh Idris Ramulyo, 1990: 140-141).

Selain pendapat di atas, Fatwa Majelis Ulama Indonesia DKI Jakarta tanggal 30 September 1986 tentang Perkawinan Antar Agama berdasarkan pendapat dalam sidang pleno tanggal 2 Agustus 1986 dan tanggal 30 September 1986 berdasarkan Keputusan Musyawarah Nasional ke II Majelis Ulama Indonesia tanggal 1 Juni 1980 yang menganjurkan dilarang perkawinan antara wanita muslim dengan laki-laki musyrik dan laki-laki muslim dilarang kawin dengan yang bukan beragama Islam (larangan mutlak). Pendapat dari pihak Gereja pada prinsipnya juga melarang dilakukannya perkawinan lintas agama. Hal ini dapat dilihat dalam Keputusan Seminar perkawinan antara agama di Universitas Katolik Atmajaya tanggal 1987, di mana dalam seminar tersebut diambil sebuah keputusan yang pada prinsipnya pihak Gereja melarang perkawinan campur antara agama.(Moh Idris Ramulyo, 1990: 142).

Selain fatwa Majelis Ulama Indonesia dan hasil seminar perkawinan lintas agama di atas, organisasi masyarakat Islam Muhammadiyah juga mengeluarkan fatwa terkait perkawinan lintas agama. Secara umum organisasi ini juga sependapat dengan pendapat jumhur ulama, yaitu laki-laki muslim tidak dibenarkan mengawini perempuan musyrik, sedangkan perempuan muslim tidak benar dikawinkan dengan laki-laki musyrik dan ahli kitab. Namun terkait laki-laki muslim mengawini perempuan ahli kitab, awalnya organisasi 
ini sepakat dengan pendapat ulama yang memperbolehkan berdasarkan ketentuan Al-Qur'an dalam surat Al-Maidah ayat 5 yang berbunyi: "Pada hari ini dihalalkan bagimu yang baik-baik. Makanan (sembelihan) orang-orang yang diberi Al Kitab itu halal bagimu, dan makanan kamu halal (pula) bagi mereka. (Dan dihalalkan mangawini) wanita yang menjaga kehormatan diantara wanita-wanita yang beriman dan wanita-wanita yang menjaga kehormatan di antara orang-orang yang diberi $\mathrm{Al}$ Kitab sebelum kamu, bila kamu telah membayar mas kawin mereka dengan maksud menikahinya, tidak dengan maksud berzina dan tidak (pula) menjadikannya gundikgundik. Barangsiapa yang kafir sesudah beriman (tidak menerima hukum-hukum Islam) maka hapuslah amalannya dan ia di hari kiamat termasuk orang-orang merugi", sehingga hukumnya mubah. Kemubahan di sini harus dihubungkan dengan alasan tertentu. Akan tetapi selanjutnya organisasi ini menghukumi haram perkawinan lintas agama, karena adanya dampak negatif yang muncul. Pertama beralihnya agama suami yang dianut agama isterinya, kedua pada umumnya agama yang dianut anaknya sama dengan agama yang dianut ibunya. Kedua alasan inilah yang dijadikan dasar pengharaman perkawinan lintas agama melaui metode saddu adzdzari'ah (upaya seorang mujtahid untuk menetapkan larangan terhadap satu kasus hukum yang sebenarnya mubah, karena sifat metode ini adalah preventif yaitu segala sesuatu yang mubah jika akan membawa perbuatan haram (misalnya keluar dari Islam), maka hukumnya menjadi haram). (Suhadi, 2006: 47-48).

Kompilasi Hukum Islam (KHI) secara tegas menyatakan bahwa Islam melarang seorang laki-laki menikah dengan seorang perempuan yang tidak beragama Islam, begitu pula sebaliknya. Ketentuan ini dinyatakan dalam ketetuan Kompilasi Hukum Islam sebagai berikut :

Pasal 40 :

Dilarang melangsungkan perkawinan antara seorang pria dengan seorang wanita karena keadaan tertentu:

a. karena wanita yang bersangkutan masih terikat satu perkawinan dengan pria lain;

b. seorang wanita yang masih berada dalam masa iddah dengan pria lain;

c. seorang wanita yang tidak beragama Islam.

Pasal 44 :

Seorang wanita Islam dilarang melangsungkan perkawinan dengan seorang pria yang tidak beragama Islam.

Dengan demikian dapat disimpulkan bahwa Kompilasi Hukum Islam sebagai hukum materiil bagi umat Islam secara jelas dan tegas melarang perkawinan antara seorang laki-laki muslim dengan 
perempuan non muslim atau sebaliknya perkawinan antara seorang wanita muslim dengan laki-laki non muslim. Dan hal ini secara tegas dinyatakan dalan firman Allah SWT dalam surat Al-Baqarah ayat 221: "Dan janganlah kamu menikahi wanita-wanita musyrik, sebelum mereka beriman. Sesungguhnya wanita budak yang mukmin lebih baik dari wanita musyrik, walaupun dia menarik hatimu. Dan janganlah kamu menikahkan orang-orang musyrik (dengan wanitawanita mukmin) sebelum mereka beriman. Sesungguhnya budak yang mukmin lebih baik dari orang musyrik, walaupun dia menarik hatimu. Mereka mengajak ke neraka, sedang Allah mengajak ke surga dan ampunan dengan izin-Nya. Dan Allah menerangkan ayat-ayatNya (perintah-perintah-Nya) kepada manusia supaya mereka mengambil pelajaran".

Menurut Ahmad Sukarja sebagaimana dikutip Suhadi, larangan perkawinan beda agama ini menjadi lebih kuat karena Undang-Undang Perkawinan Pasal 2 ayat (1) menyatakan bahwa Perkawinan adalah sah apabila dilakukan menurut hukum masingmasing agamanya dan kepercayaannya itu. Di samping itu ketentuan Pasal 8 (f), bahwa Perkawinan dilarang antara dua orang yang mempunyai hubungan yang oleh agamanya atau peraturan yang berlaku, dilarang kawin. Ketentuan ini dibuat dengan pertimbangan bahwa pertama, perkawinan lintas agama lebih banyak menimbulkan persoalan, karena adanya perbedaan prinsipil dalam ajaran agama, kedua, Kompilasi Hukum Islam mengambil pendapat ulama Indonesia termasuk Majelis Ulama Indonesia.(Suhadi, 2006: 52-53).

Secara tegas sebenarnya Undang-Undang Perkawinan juga melarang perkawinan lintas agama, yaitu pada dapat dilihat di dalam ketentuan Pasal 6 ayat 5 Undang-Undang Perkawinan, bahwa Ketentuan tersebut ayat (1) sampai dengan ayat (5) pasal 6 berlaku sepanjang hukum masing-masing agamanya dan kepercayaannya itu dari yang bersangkutan tidak menentukan lain. Selain itu ketentuan Pasal 8 huruf $\mathrm{f}$ Undang-Undang Perkawinan, bahwa Perkawinan dilarang antara dua orang yang mempunyai hubungan yang oleh agamanya atau peraturan yang berlaku, dilarang kawin.

Berdasarkan uraian di atas maka dapat dilihat bahwa perkawinan lintas agama dalam pelaksanaannya dapat menimbulkan berbagai permasalahan yang dihadapi oleh suami isteri yang berbeda agama. Di satu sisi secara aturan perundang-undangan perkawinan lintas agama tidak diperbolehkan karena melihat berbagai dampak yang mungkin ditimbulkan, serta dari segi keabsahan suatu perkawinan merupakan ranah atau kewenangan agama dan kepercayaan masing-masing agamanya. Walaupun pada kenyataannya masih banyak terjadi praktek perkawinan lintas agama, 
dengan dalih rasa cinta, kasih saying, hak asasi manusia, dan sebagainya yang mendasarkan pada teori-teori seperti Teori Hak Asasi Manusia (HAM), Teori Hukum Pembangunan, Teori Pluralisme Hukum dan Unifikasi Hukum, Teori Chaos, dan Teori Sistem Hukum Berbasis Agama, serta teori-teori yang lain.

\section{Kesimpulan}

Pandangan terhadap perkawinan lintas agama di Indonesia baik menurut hukum positif maupun hukum agama, bahwa perkawinan lintas agama dapat menimbulkan berbagai permasalahan yang dihadapi oleh suami isteri yang berbeda agama, terkait dengan kehidupan rumah tangga yang dijalani, serta tujuan perkawinan yang hendak dicapai. Selain itu berdasarkan aturan perundang-undangan, perkawinan lintas agama tidak diatur karena melihat berbagai dampak yang mungkin ditimbulkan, serta dari segi keabsahan suatu perkawinan merupakan ranah atau kewenangan agama dan kepercayaan masing-masing agamanya, sehingga adanya upayaupaya yang dilakukan oleh pihak-pihak yang ingin melangsungkan perkawinan lintas agama dengan cara-cara yang mungkin dapat ditempuh haruslah mendapat pengaturan yang lebih jelas, sehingga Undang-Undang Perkwinan benar-benar dapat memberikan pengaturan yang jelas dan tegas mengenai perkawinan lintas agama.

\section{Daftar Pustaka}

Abdurrachman dan Ridwan Syahrani. 1978. Masalah-Masalah Hukum Perkawinan Di Indonesia. Bandung: Alumni.

Hilman Hadikusuma. 2007. Hukum Perkawinan Indonesia. Bandung: CV. Mandar Maju.

Iman Sudiyat. 1981. Hukum Adat Sketsa Asas. Yogyakarta: Liberty.

KH. Ahmad Azhar Basyir. 2004. Hukum Perkawinan Islam. Yogyakarta: UII Press.

M. Idris Ramulyo. 1990. Tinjauan Beberapa Pasal Undang-Undang Nomor 1 Tahun 1974 Dari Segi Hukum Perkawinan Islam. Jakarta: IND-HILL$\mathrm{CO}$.

Moh. Idris Ramulyo. 2002. Hukum Perkawinan Islam. Jakarta: PT. Bumi Aksara.

Otje Salman Soemadiningrat. 2002. Rekonseptualisasi Hukum Adat Kontemporer. Bandung: PT. Alumni.

Siska Lis Sulistiani. 2015. Kedudukan Hukum Anak Hasil Perkawinan Beda Agama Menurut Hukum Positif dan Hukum Islam. Bandung: PT. Refika Aditama.

Sirman Dahwal. 2016. Hukum Perkawinan Beda Agama dalam Teori dan Praktinya di Indonesia. Bandung: Mandar Maju. 
Syarafuddin HZ, et al. 2003. Studi Islam 2. Surakarta: Lembaga Studi Islam (LSI) UMS.

Subekti. 1989. Pokok-pokok Hukum Perdata. Jakarta: PT. Intermasa.

Suhadi. 2006. Kawin Lintas Agama Perspektif Kritik Nalar Islam. Yogyakarta: LKiS Yogyakarta.

Sunaryati Hartono. 1991. Politik Hukum Menuju Satu Sistem Hukum Nasional. Bandung: Alumni.

Undang-Undang Nomor 1 Tahun 1974 Tentang Perkawinan.

Instruksi Presiden Nomor 1 Tahun 1991 Tentang Kompilasi Hukum Islam. 